\title{
A Survey on the potential of monitoring of longwall complex parameters based on industry 4.0
}

\author{
Patryk Szolc ${ }^{1}$, Marta Stempniak ${ }^{2}$, Remigiusz Grudziecki², and Dorota Pałka ${ }^{3 *}$ \\ ${ }^{1}$ Polska Grupa Górnicza S.A., KWK ROW ruch Chwałowice, ul. Przewozowa 4, 44-206 Rybnik, \\ Poland \\ ${ }^{2}$ Wrocław University of Technology, Faculty of Geoengineering, Mining and Geology, ul. Na Grobli \\ $15,50-421$ Wrocław \\ ${ }^{3}$ Silesian University of Technology, Faculty of Organization and Management, Roosevelta 26, \\ 41-800 Zabrze, Poland
}

\begin{abstract}
A brief description of the program of Industry 4.0 and the impact it has on the economy and its development provided by the students show how the young generation sees the concept-a reality they themselves will soon be engage in as workers. The paper discusses the principles of Industry 4.0 and what they mean to Polish economy. The authors developed a survey and conducted it among students of the Wrocław University of Technology, Faculty of Geoengineering, Mining and Geology, and engineers from the Polska Grupa Górnicza S.A. KWK ROW Ruch Chwałowice. The survey was of an informative nature. It covered a group of underground workers holding different positions including miners, electricians or mechanical fitters. The respondents are employed to carry on various tasks related to operation and maintenance of mining machinery and devices. The questionnaire consists of 15 questions. They were arranged in such a way that the participants could respond in an efficient and quick way. Additionally, the questionnaire contained information about the seniority of a given employee, education and age. The results of the survey demonstrate how employees understand technological change. They can be helpful in implementing the development and implementation of new technologies.
\end{abstract}

\section{Introduction}

To maintain the world economy at current level requires 38 percent of energy to be generated from hard coal. Abandoning this energy raw material and increasing the production of oil or gas is rather impossible. Ensuring extraction at current levels in the next 10 years will be quite difficult. This will be mainly due to the increase in natural hazards $[16,17]$. There are numerous types of such hazards, but the main ones are methane hazards $[13,14,15]$, fire hazards [10] and tremors [12]. As the depth of operation increases, a higher temperature and dustiness harmful to health can be recorded. Such environment

\footnotetext{
${ }^{*}$ Corresponding author: dorota.palka@polsl.pl
} 
will require the implementation of technologies that had already been developed and tested [1] as well as new ones [2].

Industry 4.0 is a complex process of technological and organizational transformation in a company which aims to integrate a man, a machine, equipment and the Internet [4]. The concept of Industry 4.0 [5] therefore means the unification of the real world of production machines with the virtual world of the Internet and information technology, as illustrated in Figure 1 [9]. The implementation of this program involves a change in the organisation of production in a company. This translates into a significant increase in production flexibility, resulting in a change in the producer-consumer relationship model. The idea is to move away from the model of mass production, where the customer was dependent on the manufacturer's initiative, and head to the new model included in the Industry 4.0 program, which assumes mass personalisation and involves close cooperation of both groups [7]. The prerequisite for the transformation is the advanced use of digital technologies and data resources to achieve business success and gain advantage in the market in which a company operate. The use of digital technologies and a change in the company's strategy provide opportunities for cost-effective, personalized production to meet individual customer needs [4].

The companies that have introduced the Industry 4.0 program operate in global cooperation of digital factories. These include intelligent machines, storage systems and production facilities, which form a cyber-physical system, so-called CPS [4]. In terms of robotization, Poland is still far behind the world average, which is 74 robots per 10,000 workers. In Poland, there are about 32 robots (182 in the automotive industry) per 10,000 workers. This means a high potential for the development of this part of the industry, which is very visible and translates into an increase in the number of machines used by about $15 \%$ [8]. Underground mining currently does use tools developed on the basis of the Industry 4.0 program. They are used, among other things, in the modeling of the deposit based on the $3 \mathrm{D}$ technique with the use of modern surveying instruments for underground measurements.

The paper presents the way students and mine workers perceive the potential of digitization and robotization of the mining industry. The article discusses the results of the survey concerning the knowledge of employees of one of the mines about the Industry 4.0 program.

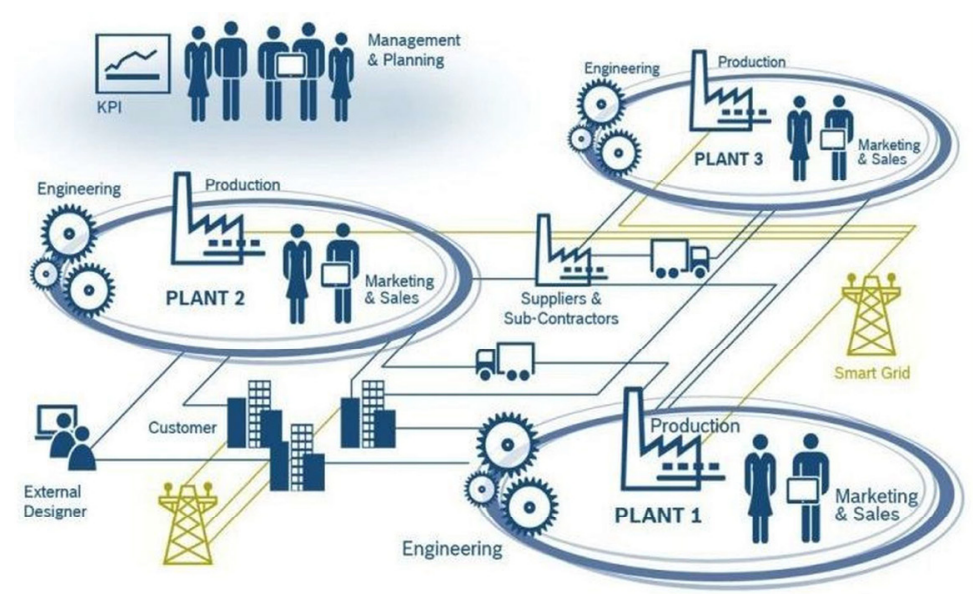

Fig. 1. Production model featuring the idea of Industry 4.0 [9]. 


\section{The relevance of industry 4.0 in machine performance monitoring}

A powered roof support system for underground coal mining consists of the following machines: a shearer, a scraper conveyor and a powered roof support. The shearer performs the function of a mining machine by moving on a longwall conveyor, which transports the coal. The powered roof support is designed to protect these machines, preventing rock mass from moving into the working space. The monitoring of these machines, and in particular of the powered roof supports, is very important and affects the work safety and economic performance.

Technology driven by the fourth revolution supports new business models. Every, even strong companies, invests in adapting its production to a changing world [6]. Mining as a demanding heavy industry in the face of a changing world needs to adapt its mining methods to maintain its market position. In the last two years, Polska Grupa Górnicza has introduced the monitoring of parameters of work of powered roof supports in a longwall complex. Monitoring of operating parameters involves the use of appropriate sensors and preventive algorithms to predict the occurrence of failures and implementation of mobile devices ensuring constant access to documentation and on-line previews of operating parameters. Figure 2 shows the machines that are part of the Caterpillar mining complex.

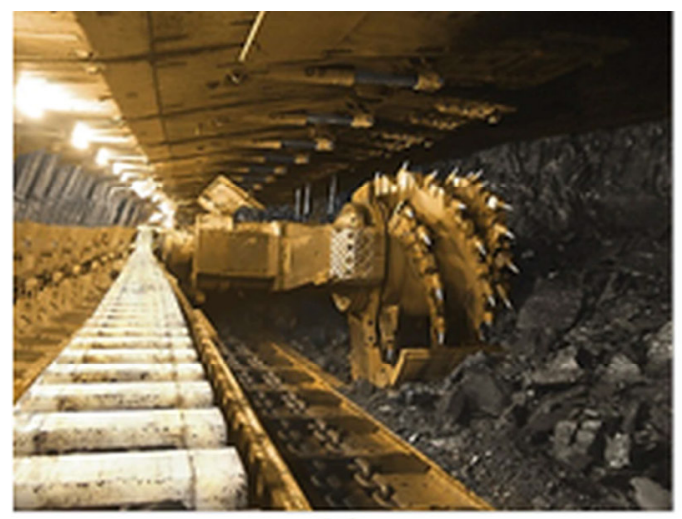

(a)

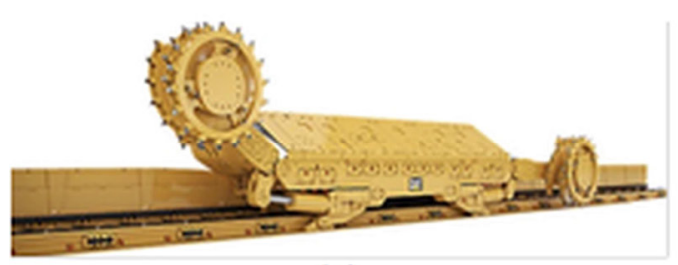

(c)

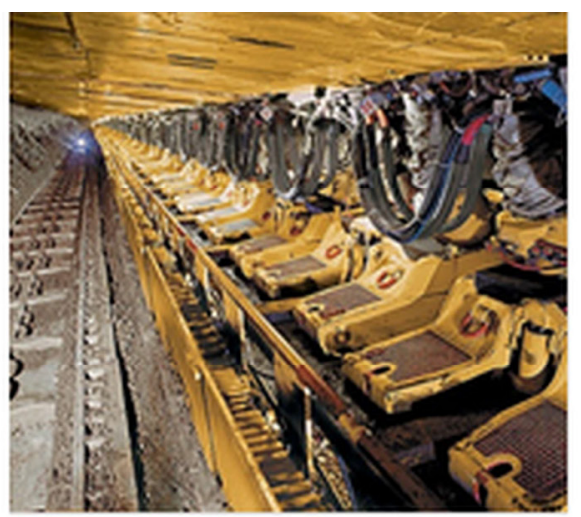

(b)

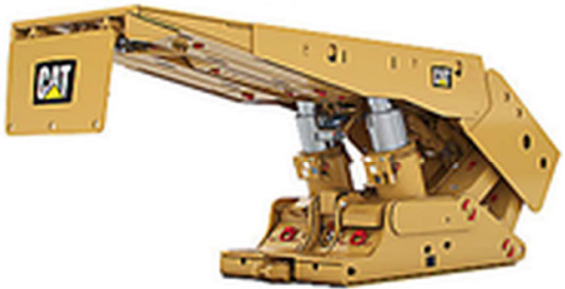

(d)

Fig. 2. Machines included in the longwall complex: (a) a shearer and a scraper conveyor in the longwall; (b) a powered roof support in the longwall; (c) a longwall shearer; (d) a section of the powered roof supports (www.cat.com).

A good example of technology and implementation based on the Industry 4.0 are solutions introduced by Centrum Hydrauliki DOH Sp. z o.o. from Bytom, Poland. It designs and manufactures hydraulic control systems for powered roof supports. Thanks to the support of EU programmes, it has extended the range of its products with wireless monitoring of operating parameters of powered roof supports. This integrated monitoring 
network consists of wireless sensors mounted mainly in hydraulic legs of the support section. In combination with the data analysis software, a reliable monitoring system can be designed [11].

The Polish industry is dominated by companies that are only partially automated. This offers opportunity for further development of IoT. Steady decline of percentage of nonautomated companies shows that Polish industry undergoes constant development and improvement [18]. With a great potential for business automation, Polish companies must ensure that these revolutionary changes are properly implemented so that they actually create new opportunities instead of further issues. It is necessary to monitor and constantly verify the direction of the changes and plans of modern solutions, because inappropriate attempts to implement poorly developed systems may only lower the quality of processes, especially in such dynamically changing environment as Polish industry. It is important that the activities introduced successively respond precisely to the needs of a company and the specialists involved in the investment stage must precisely identify the problem to be solved by a machine. New equipment should positively affect the company's financial results. In order to make improvements, it is necessary to know exact parameters of the introduced machine.

Each device needs a certain amount of power. Prior to applying new equipment that will operate underground, it is crucial to calculate power consumption of a given device or machine. Otherwise, people working with it or near it may be exposed to danger. In the case of a combustion engine, an adequate ventilation system must be provided, and in the case of electric power supply, wiring or charging stations. This is another important variable forcing the manufacturers to calculate and properly implement the latest trends. They must also remember that automation is a process that lasts for a longer period of time (its length depends on the size of the company and the complexity of new machines) [18]. When designing the operation of machines, it is important to integrate them with the rest of the company.

All processes, starting from the extraction of the material, through transport and sale, must be synchronised so that no downtime occurs at any stage. Insufficient knowledge of concepts of Industry 4.0 can result in a misbalance between the different parts of the company, which in turn leads to drop in profits. Successive introduction of machines does not exclude human factors. It should be remembered that reducing the demand for human workforce does not result in its complete exclusion. This results in a need to introduce new trainings that will allow employees to effectively supervise work and the company will provide employees with professional development. This motivates both larger and smaller companies to employ a larger group of employees who will take care of the programming of new equipment and provide induction training for other employees [18]. Furthermore, companies that strive to develop this area should have the capital in the amount that will allow them to introduce and develop programs for new machines. Strong intellectual capital will result in long-term productivity. Research and development are essential components for any company determined to introduce the concepts of the fourth industrial revolution [18].

\section{Survey on understanding the potential of Industry 4.0}

The survey was conducted in a group of 100 employees working in an underground hard coal mine. The respondents were employees of mechanical, electrical and mining departments. The age of the respondents ranged from 20 to 52 years, their seniority ranged from 1 year to 27 years. The division of the control group according to the department in which the respondents work is shown in Figure 3. The questionnaire sheet is shown in Figure 4. 


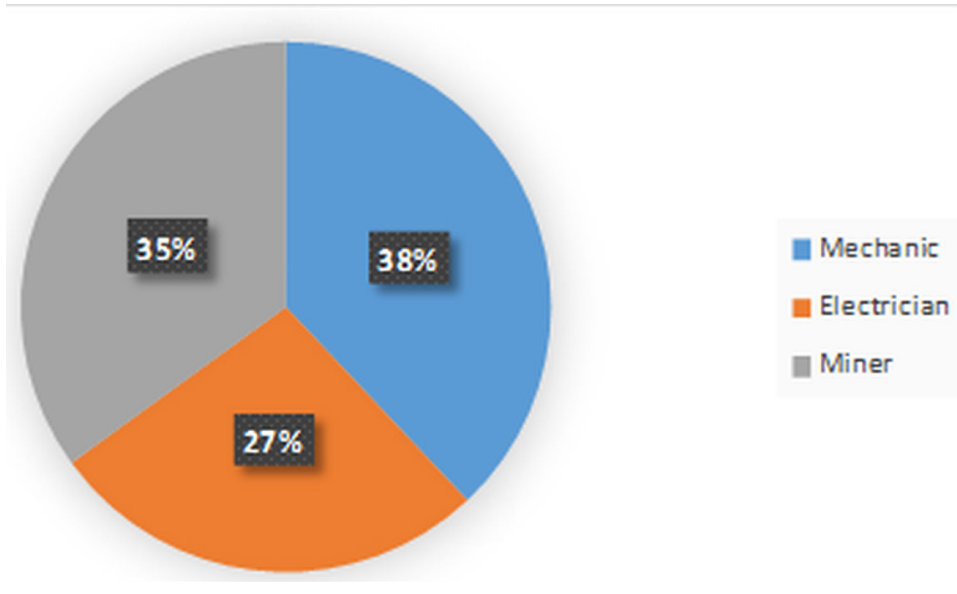

Fig. 3. The groups of respondents

Table 1. Questionnaire sheet on the Industry 4.0 conducted among employees of a mine.

\begin{tabular}{|c|c|c|c|c|}
\hline $\begin{array}{c}\text { Item } \\
\text { no. }\end{array}$ & Area of the research & Yes & No & $\begin{array}{l}\text { Don't } \\
\text { know }\end{array}$ \\
\hline 1 & Do you know what Industry 4.0 is? & & & \\
\hline 2 & Is Industry 4.0 known in Poland? & & & \\
\hline 3 & $\begin{array}{l}\text { Do you support the introduction of Industry } 4.0 \\
\text { to the mines? }\end{array}$ & & & \\
\hline 4 & $\begin{array}{l}\text { Can Industry } 4.0 \text { influence the Polish mining } \\
\text { industry? }\end{array}$ & & & \\
\hline 5 & Can companies benefit from it? & & & \\
\hline 6 & $\begin{array}{l}\text { Can an employee also benefit from the } \\
\text { introduction of advanced technologies? }\end{array}$ & & & \\
\hline 7 & $\begin{array}{l}\text { Can the environment benefit from such an } \\
\text { industrial model? }\end{array}$ & & & \\
\hline 8 & $\begin{array}{l}\text { Have there been any changes in this direction in } \\
\text { your environment over the past years? }\end{array}$ & & & \\
\hline 9 & Is monitoring necessary? & & & \\
\hline 10 & $\begin{array}{l}\text { Does monitoring of mining machinery affect the } \\
\text { quality of work? }\end{array}$ & & & \\
\hline 11 & $\begin{array}{l}\text { Should the monitoring be carried out on a } \\
\text { specific machine? }\end{array}$ & & & \\
\hline 12 & Does monitoring affect the rate of work? & & & \\
\hline 13 & $\begin{array}{l}\text { Should the monitoring be carried out in the entire } \\
\text { longwall complex? }\end{array}$ & & & \\
\hline 14 & $\begin{array}{l}\text { Do you support the training of employees in } \\
\text { terms of future work based on Industry } 4.0 ?\end{array}$ & & & \\
\hline 15 & $\begin{array}{l}\text { Would you like to know more about Industry } \\
4.0 \text { ? }\end{array}$ & & & \\
\hline
\end{tabular}

More than a half $(53 \%)$ of the respondents stated that they do not know what the Industry 4.0 is, and $34 \%$ of the respondents do not know if Industry 4.0 is known in Poland. 47 of respondents support the introduction of Industry 4.0 to mines. The majority, namely $64 \%$, believe that Industry 4.0 may affect the Polish mining industry and believe that companies can benefit from it $(62 \%)$. Less than a half $(55 \%)$ think that an employee can benefit from the introduction of advanced technologies and $43 \%$ of the respondents stated that such an industry model can be beneficial to the environment whereas $45 \%$ do not have 
an opinion. The respondents also do not know if there have been any changes in their environment related to this issue in recent years (44\% of responses). However, $57 \%$ of the respondents considered monitoring to be necessary, and $62 \%$ of the respondents said that monitoring of mining machinery affects the quality of work. The majority $(54 \%)$ of the respondents believe that monitoring should include a specific machine, while $68 \%$ of the respondents support monitoring of the entire longwall complex. At the same time, 42 people stated that monitoring affects the rate of work. Questions 14 and 15 of the questionnaire were answered in the affirmative by the majority of the respondents (fig. 4).

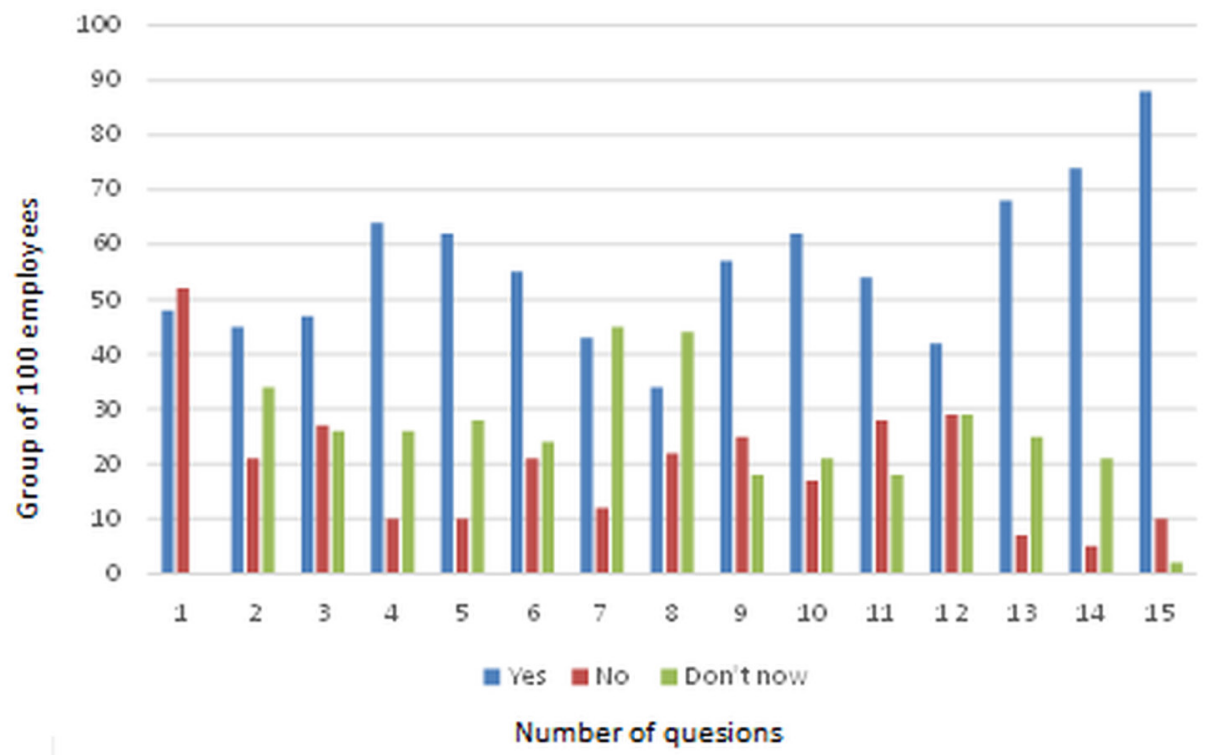

Fig. 4. Results of the survey.

\section{Conclusion}

Industry 4.0 is an investment in the future, which will allow for dynamic development of the economy and entry into a new and better era of industry in Poland. However, a survey has shown that workers' awareness of this revolution is very low. The Polish economy has been a focused mainly on development in recent years. University students are very successful in international competitions and Polish programmers are appreciated all over the world. This provides an excellent basis for dynamic development, but a reasonable plan to introduce this system to each company should be prepared.

The first step should be education. More than half of the respondents admitted that they do not the principles of Industry 4.0. The foundation of every revolution is knowledge, which should spread among society. The current education plan should be implemented in two phases. The first phase should be an extensive information training campaign for employees who will be the first to face the new work system. The second phase is the need to educate young people who are just about to enter the labour market. Young people are the future of the entire global economy and are a force that can be easily shaped. By ensuring an adequate level of education, a calm and secure supply of specialists in the future is guaranteed. The very introduction of the education system based on youth is an investment in the Industry 4.0 program. 
The second stage is to invest in modern specialists. By creating the right conditions for development for employees, their knowledge and new experience, it is possible to increase the competitiveness of companies. Seams of Polish coal are deposited at great depths. Large numbers of skilled and qualified workers will provide Polish companies with the opportunity to quickly and safely exploit these deposits, which are theoretically no longer available due to depth or temperature. The machines themselves may be solely responsible for mining and be controlled from a safe distance by an operator.

The third stage is the introduction of automated machines into Polish mines. Such investment generates substantial costs. The return is mainly related to raw material prices on world exchanges. Therefore, in order to be competitive in global markets, employers are forced to increase investments and reduce costs. This will increase the company's attractiveness on the market and young and ambitious employees will be more willing to apply for positions that offer development, adapted to the modern world and its requirements. The results of the survey show that the majority $(89 \%)$ of employees are eager to gain or deepen knowledge on the concepts of Industry 4.0.

\section{References}

1. J. Brodny, M. Tutak, Energies, 12:13, 2505 (2019)

2. J. Brodny, M. Tutak, Int. J. Environ. Res. Public Health, 15:9, 1846 (2018). DOI:doi.org/10.3390/ijerph15091846

3. M. Vermaat, S. Sebok, S. Freund, J. Campbell, M. Frydenberg, Discovering computers (Cengage Learning, Boston, 2014)

4. K. Nosalska, K. Śledziewska, R. Włoch, J. Gracel, Wsparcie dla przemystu 4.0 w Polsce. URL: http://przemysl-40.pl/wp-content/uploads/2019-Badanie-dojrzaloscifirm.pdf

5. T. Comstock, Understanding industrial transformation today Digital reading is the Foundation for Success. URL: http://przemysl-40.pl/wp-content/uploads/2019-IIoTDigital-Readiness.pdf

6. I. Deloitte, The Fourth Industrial Revolution is here - are you ready? URL: http://przemysl-40.pl/wp-content/uploads/2018-Industry40-Are-you-ready.pdf

7. I. Gracel, 4.0 Rewolucja już tu jest. Co o niej wiesz? URL: https://www.astor.com.pl/images/Industry_40_Przemysl_40/ASTOR_przemys14_white paper.pdf

8. Nowy Przemysł Expo, Polski Przemyst 4.0. URL: http://przemysl40.pl/wpcontent/uploads/2018-Raport-Expo.pdf

9. Z. Piątek, Czym jest przemyst 4.0? URL: http://przemysl40.pl/index.php/2017/03/22/czym-jest-przemysl-4-0/

10. D. Szurgacz, L. Sobik, J. Brodny, Multidiscip. Asp. Prod. Engin., 2:1, 183-190 (2019). DOI:doi.org/10.2478/mape-2019-0018

11. D. Szurgacz, J. Brodny, SGEM, 18, 793-800 (2018). DOI:doi.org/10.5593/sgem2018/1.3

12. D. Szurgacz, J. Brodny, E3S Web Conf., Vol. 41, 03019 (2018)

13. M. Tutak, Sustainability, 12:1, 16 (2020)

14. M. Tutak, J. Brodny, Appl. Sci. 9:24, 5315 (2019). DOI:doi.org/10.3390/app9245315

15. M. Tutak, J. Brodny, Energies, 12:20, 3840 (2019). DOI:doi.org/10.3390/en12203840 
16. M. Tutak, J. Brodny, Int. J. Environ. Res. Public Health, 16:8, 1406 (2019). DOI:doi.org/10.3390/ijerph16081406

17. M. Tutak, J. Brodny, Energies, 11:11, 3076 (2018)

18. D. Zaraziński, P. Szymczak, $W$ stronę Przemystu 4.0. URL: https://www.astor.com.pl/industry4/HBRP_ASTOR_w_strone_przemyslu_4_0.pdf 